\title{
SEASONAL VARIATION OF TRACE ELEMENT AND NUTRITIONAL STATUS OF CAMELS (CAMELUS DROMEDARIUS) RAISE AT FIVE REPRESENTATIVE REGIONS IN SAUDI ARABIA
}

\author{
M.M. Abdelrahman; R.S. Aljumaah and I.A. Alhidary \\ King Saud University, College of food and Agriculture Sciences, Department of Animal Production. \\ Saudi Arabia
}

\section{SUMMARY}

$\mathrm{T}$ This study was focused on the variation of copper $(\mathrm{Cu})$, zinc $(\mathrm{Zn})$, manganese $(\mathrm{Mn})$, selenium $(\mathrm{Se})$, iron (Fe), iodine (I) and cobalt in tissues of slaughtered camels, she-camels and their newborn in five regions in Saudi Arabia during summer season. Whole blood, meat, liver, tumen fluid and blood tissues were collected from the slaughter house from each region. Moreover, blood samples from shecamels and their calves were collected from the same region at the same time. Samples were analyzed for trace minerals concentrations using ICP-MS. A significant variation for all trace minerals were reported between regions. A significantly higher concentration of all trace mineral in the were reported for liver samples that collected from camels slaughtered in southern part of Saudi Arabia, except Se and I, compared with other regions. Regarding the meat samples, a significant variation was also reported between all regions, except the iodine levels. Moreover, a significant correlation coefficient were found between most of the minerals especially meat with whole blood, rumen fluid and rumen tissues. On the other hand, A significant variations were reported for all trace minerals in blood serum of she-camels between different regions, except for the iodine. The same trend was also noticed for the calves, but the exception for the cobalt not the iodine. In conclusion, regions reported a variation between most trace minerals in term of the camel's tissues from the slaughterhouse or she-camels and their newborns blood serum during the summer season.

Keywords: She-camels, calves, slaughterhouse, trace minerals, summer, regions.

\section{INTRODUCTION}

The demand for animal products in Saudi Arabia is increasing rapidly and the supply is still below the required level in part because of low animal productivity. Camel (Camelusdromedarius) is considered one of the main sources of healthy meat and milk for human consumption within SA. The number of camels in Saudi Arabia fluctuates from year to year because of variations in conditions caused by drought, erratic rainfall and global warming. Camels suffer from growth retardation of newborns, low feed efficiency, anemia, poor fertility, poor reproduction and many other metabolic disorders. It is well known that trace minerals deficiencies and trace mineral toxicities can influence camel production and reproductive efficiency, as well as many aspects of growth and metabolism.

Trace minerals are crucial for animal health and productivity including camel, especially when they become a limiting factor of the diet (Faye and Bengoumi, 2018). They play a pivotal role in many physiological activities and their deficiency causes a variety of pathological problems and metabolic defects (Deen et al., 2004). The level of nutrition and trace mineral intakes are known to affect the reproductive ability of male of female camels (El-Bahrawy and El-Hassanein, 2011; Ali et al., 2010). The trace minerals such as selenium $(\mathrm{Se})$, copper $(\mathrm{Cu})$, zinc $(\mathrm{Zn})$, manganese $(\mathrm{Mn})$, cobalt $(\mathrm{Co})$, iron $(\mathrm{Fe})$, iodine (I) and molybdenum (Mo) are involved in normal growth and productivity of livestock (Underwood, 1981). Infertility, non-infectious abortion, anemia and metabolic diseases are some of the main clinical signs of deficiencies and abnormalities (McDowell et al., 1983; Bicknell, 1995). A few scientific studies have shown some evidence of sensitivity of camels to trace mineral disorders as a result of either deficiency or toxicity in the same way as other ruminants (Faye and Bengoumi, 1994). Faye et al. (1992), Faye and Bengoumi (1994) and Liu et al. (1994) have reported several incidences of clinical mineral deficiencies in camels being underestimated because signs of subclinical deficiencies may remain undetected for long periods. Regarding toxicity, evidence is even rarer. For example, some cases of selenosis were described (Seboussi et al., 2009) as well as fluorosis (Diacono et al., 2008). 


\section{Abdelrahman et al.}

This study was designed to evaluate the status of trace minerals in slaughtered male (Meat, liver, whole blood, rumen fluid and rumen tissues), blood serum of she-camels and their calves from five regions (central, eastern, western, southern and northern regions) in Saudi Arabia during summer season.

\section{MATERIALS AND METHODS}

\section{Part I. Slaughter houses: camels' trace mineral status in tissues}

Blood and tissues sampling: Liver, meat, whole blood, rumen fluid and rumen tissues samples were collected from local slaughter houses in the five regions (central, eastern, western, southern and northern regions) to establish a variation in trace mineral between different regions during summer. Fifteen male camels from each region (> 1.5 years old) were selected in the slaughter house to be as homogeneous as possible for samples collection. In general, sampling was performed during the summer season from each five regions. Rumen fluid and tissues were collected from only two regions (central and eastern regions). Whole blood and tissue samples were stored at $-20^{\circ} \mathrm{C}$ until further analysis.

\section{Part 2. Survey of trace minerals of she-camels and their calves}

Thirty healthy female camels and their newborns ( $<6$ month old) from each region were selected according to female camels' physiological status and health. Blood samples were collected from the shecamels and their newborn during the summer season from the five regions. Blood samples were centrifuged at $3000 \mathrm{rpm}$ for 15 minutes to separate serum.

\section{Laboratory work}

All samples were prepared and well digested by acid wet ashing (AOAC, 1995) and analyzed for trace minerals concentration using IC-PMS.

\section{Statistical analysis}

Data were analyzed by a complete randomized design using SAS (2003). Dependent variable was the trace mineral concentration and independent variable was the region. Correlation coefficient between slaughter house tissues and she-camels with calves trace mineral status was conducted by Pearson correlation test. Level of significance was $\mathrm{P}<0.05$.

\section{RESULTS AND DISCUSSION}

It has been well documented that factors such as the level of nutrition, mineral availability and mineral utilization affect production and reproductive ability of both males and females of ruminant animals. Trace minerals are essential nutrients and play an important role in animal nutrition. Either a deficiency or an excess of these compounds can cause a detrimental effect on the performance and health of ruminants. Trace minerals such as selenium, copper, zinc, manganese, cobalt, iron and iodine are very important for normal growth and function of ruminant animals (Underwood, 1981). In general, few studies regarding trace minerals and other nutritional status of camels in Saudi Arabia and other countries have been reported in the literature, and the majority of these fail to consider the main factors that affected this status, such as season, age, breed, sex, physiological status and management risk factors (especially those linked to the feeding system). Most of the studies focus on the levels of minerals in the main camel products (meat and milk) or in serum and tissues, without focusing on factors such as season and physiological status which are necessary to obtain solid background information for developing seasonal mineral supplementation programs. Furthermore, no reported studies have been found in the literature regarding the mineral status of camels in the main five regions (Central, western, eastern, southern and northern regions) of Saudi Arabia, where camel rearing is preponderant, over the course of a complete year. This information is crucial to improving camel productivity by correcting deficiencies (through developing mineral supplementation programs) during specific times of the year. So, information regarding the trace mineral status of camels during different physiological status is very crucial and important to be known for dietary supplementation. Zinc $(\mathrm{Zn})$, copper $(\mathrm{Cu})$, manganese $(\mathrm{Mn})$, 
cobalt (Co), selenium (Se), Iron ( $\mathrm{Fe}$ ) and iodine (I) are the most important trace minerals for different stages of production, especially lactation, for proper performance. Moreover, meat and liver of camels is considered one of the main protein and other nutrients in the food chain.

The results for the trace minerals concentration in liver and meat samples from young camels, $>1.5$ years, from the slaughter house of five regions in Saudi Arabia are reported in table 1 and 2. A significant variation for all trace minerals were reported between regions. A significantly higher liver concentration of all trace mineral were reported for camels slaughtered in southern part of Saudi Arabia, except Se and I. Moreover, camels from other regions, except the northern and southern regions, were not significantly differing in most of the trace minerals, except $\mathrm{Cu}$.

Regarding the meat samples, significant variations were reported between all regions, except the iodine levels. A significantly higher concentration were reported for $\mathrm{Zn}, \mathrm{Fe}$ and $\mathrm{Co}$ for camels raised in the southern region compared with others. For the rumen fluid and tissues, variation reported for $\mathrm{Cu}$ in the rumen fluid and rumen tissues between the camels raised in the central and eastern regions (Tables 3 , 4 and 5).

A significant correlation coefficient were reported between most of the minerals especially meat with whole blood, rumen fluid and rumen tissues. There was no significant correlation reported between liver and other tissues. A significant correlation between different tissues of camels were reported for Se (rumen fluid and tissues, liver and meat, whole blood and meat, rumen fluid and meat, rumen tissues and liver and meat); Mn (Rumen tissues and whole blood, meat and rumen fluid; rumen fluid and whole blood; whole blood and meat); $\mathrm{Zn}$ (Whole blood and meat; rumen fluid and meat and whole blood; rumen tissues and meat and whole blood and rumen fluid); Se (liver and meat; whole blood and meat; rumen fluid and meat whole blood; rumen tissues and liver and meat); $\mathrm{Cu}$ (rumen tissues and meat, whole blood and rumen fluid; whole blood and meat); $\mathrm{Fe}$ ( rumen fluid rumen tissues and whole blood; rumen tissues and meat); Co 9 rumen tissues and meat; rumen tissues and rumen fluid); I (rumen fluid and meat; whole blood and liver).

The trace minerals concentration in she-camels and their calveswere determined. A significant variation was reported for all trace minerals in blood serum of she-camels between different regions, except for the iodine. The same trend was also reported for the newborn, but the exception for the cobalt not the iodine.

All these variations mainly related to the production system and heat stress during summer. Camels are well adapted to the harsh environment in arid and semi-arid areas following different biological mechanism such as: increased absorption of $\mathrm{Cu}$ and $\mathrm{Zn}$ under deficient conditions (Faye et al., 1999); high storage capacity in case of $\mathrm{Cu}$ deficiency (Faye and Bengoumi, 1997); the ability to tolerate excess minerals and electrolytes (Bengoumi and Faye, 2002); the ability to maintain the activities of key mineral-dependent enzymes such as GSH-Px (Bengoumi et al., 1998; Essamadi et al., 1998). This can explain the different mechanism for each trace minerals and their varied correlation from tissue to another.

The biology of camel appears as a physiological system able to anticipate the period of resources' restriction (water and feed). This biological behavior with trace-elements complies with the mechanisms of water preservation, urea recycling, fat storage management or homeostasis of electrolytes which provide a superiority of camel in the harsh desert environment. However, despite these adaptations, camels in arid and semi-arid countries can suffer from a variety of mineral deficiencies, which are often undetected and untreated resulting in significant economic loss, notably in intensive systems, more demanding in term of production performances. Up to now, the adequate and toxic levels of trace minerals in blood serum and tissues of camels are not well defined in the literature and great variation shown. So, further research is required to precisely identifying these levels.

\section{CONCLUSION}

From the above results, regions reported a variation between most of the trace minerals in term of the camels' tissues from the slaughter house or she-camels and their calves' blood serum during the summer season. Camel's biological mechanism for trace minerals is differing from one to another in term of the biological adaptation in arid and semi-arid regions. 


\section{ACKNOWLEDGEMENT}

This project was funded by the National Plan for Science, technology and Innovation (MAARIFAH), King Abdulaziz City for Science and Technology, Kingdom of Saudi Arabia, Award number (13AGR1208-02).

\section{REFERENCES}

Ali, A., M. Tharwat and L. Al-Sobayl (2010). Hormonal, biochemical, and hematological profiles in female camels (Camelus dromedaries) affected with reproductive disorders. Animal Reproduction Science, 118(2) : 372-376, https://doi.org/10.1016/j.anireprosci.2009.08.014.

AOAC (1990). Official methods of Analysis, Washington, DC, USA .

Bengoumi, M., A.K. Essamadi, J.C. Tressol, J.P. Chacornac B. Faye (1998).Comparative effect of and erythrocyte glutathione peroxidase activity in cattle and camel.Animal Sciences, 67: 461-466. https://doi.org/10.1017/s1357729800032872

Bengoumi, M. and B. Faye (2002). Adaptation du dromadaire à la déshydratation. Revue Secheresse, 13 : 121-129. https://doi.org/10.19182/remvt.9849

Bicknell, D.V.M. (1995). Trace minerals and reproduction. Zimbabwe Herd Book, 21: 19.

Bowman, G., J. Richards and M. Vázquez-Añión (2008). Improving the antioxidant status of the dairy cow through nutrition.Intermountain Nutrition Conference. January 29-30. Salt Lake City, UT.

Deen, A., A. Bhati and M. Sahani (2004). Trace mineral profiles of camels blood and sera. Journal of Camel Practice and Research, 11: 135-136.

Diacono, E., A. Meldebekova, G. Konuspayeva and B. Faye (2008). Plant, Water and Milk pollution in Kazakhstan. Proc. of Intern. Workshop, "Impact of pollution on animal products". Almaty (Kazakhstan), 27-30 Septembre 2007, B. Faye and Y. Sinyavskiy (Eds), 107-116.

El-Bahrawy, K. and E.E. El Hassanein (2011). Seasonal variation of some blood and seminal plasma biochemical parameters of male Dromedary camel. American-Eurasian Journal of Agriculture and Environment Science. 10(3): 354-360.

Essamadi, A.K., M. Bengoumi, J.P. Chacormac and B. Faye (1998). Relationship between plasma copper concentration and ceruloplasmin activity in camel. Trends in Comparative Biochemistry and Physiology, 5: 211-220.

Faye, B. and M. Bengoumi (2018). Camel clinical biochemistry and hematology. Chapter 7. Trace Elements, Springer Publ., New-York, 217-274. https://doi.org/10.1007/978-3-319-95562-9 7

Faye, B., G. Saint-Martin and R. Cherrier (1992). The influence of high dietary protein, energy, and mineral intake on deficient young camels (Camelus dromedaries). I. Change in mineral status. Comparative Biochemistry and Physiology, 102: 417-424. https://doi.org/10.1016/03009629(92)90156-k

McDowell, L.R., J.H., Conrad, G.L. Ellis and J.K. Loosli (1983). Minerals for grazing ruminants in tropical regions. Centre for Tropical Agriculture University of Florida Gainesville and the US Agency for International Development.

SAS Institute. SAS User's Guide.Statistics (2003), Version 8 ed. SAS Inst. Inc., Cary, NC.

Seboussi, R., B. Faye, G. Alhadrami, M. Askar, M. Bengoumi and A. Elkhouly (2009). Chronic selenosis in camels. Journal of Camel Practice and Research, 16(1): 25-38.

Underwood, E.J. (1981). The incidence of trace element deficiency diseases. Philosophical Transactions of the Royal Society London B, Biological Sciences, 294(1071): 3-8. https://doi.org/10.1098/rstb.1981.0085 
Table (1): The some trace minerals concentration in growing camels' liver ( $\mu \mathrm{g} / \mathrm{g} \mathrm{WW})$ raised under semi-arid condition of five regions during summer, Saudi Arabia

\begin{tabular}{lccccccc}
\hline Region & $\mathrm{Cu}$ & $\mathrm{Zn}$ & $\mathrm{Se}$ & $\mathrm{Mn}$ & $\mathrm{Fe}$ & $\mathrm{I}$ & Co \\
\hline Central & $108.81^{\mathrm{b}}$ & $56.50^{\mathrm{b}}$ & $15.63^{\mathrm{b}}$ & $26.47^{\mathrm{b}}$ & $79.11^{\mathrm{b}}$ & $2.38^{\mathrm{b}}$ & $2.02^{\mathrm{b}}$ \\
Eastern & $130.31^{\mathrm{c}}$ & $59.56^{\mathrm{b}}$ & $17.79^{\mathrm{b}}$ & $18.57^{\mathrm{b}}$ & $113.48^{\mathrm{b}}$ & $2.75^{\mathrm{b}}$ & $1.38^{\mathrm{b}}$ \\
Western & $179.19^{\mathrm{c}}$ & $62.83^{\mathrm{b}}$ & $22.66^{\mathrm{b}}$ & $19.06^{\mathrm{b}}$ & $104.96^{\mathrm{b}}$ & $2.49^{\mathrm{b}}$ & $1.13^{\mathrm{b}}$ \\
Southern & $251.60^{\mathrm{a}}$ & $114.07^{\mathrm{a}}$ & $15.79^{\mathrm{b}}$ & $163.28^{\mathrm{a}}$ & $714.44^{\mathrm{a}}$ & $2.14^{\mathrm{b}}$ & $5.02^{\mathrm{a}}$ \\
Northern & $97.09^{\mathrm{b}}$ & $49.98^{\mathrm{b}}$ & $56.34^{\mathrm{a}}$ & $23.14^{\mathrm{b}}$ & $98.148^{\mathrm{b}}$ & $4.08^{\mathrm{a}}$ & $1.21^{\mathrm{b}}$ \\
SEM & 17.17 & 7.12 & 3.82 & 2.56 & 9.66 & 0.20 & 0.17 \\
Significancy & $*$ & $*$ & $* *$ & $*$ & $*$ & $* *$ & $*$ \\
\hline
\end{tabular}

$S E M=$ Standard error of means

Value within column followed with different superscripts are significantly differ

$*=P<0.5 ; * *=P<0.01 * * *=P<0.001$.

Table (2): The some trace minerals concentration in growing camels' Meat $(\mu \mathrm{g} / \mathrm{g} \mathrm{WW})$ raised under semi-arid condition of five regions during summer, Saudi Arabia

\begin{tabular}{lcccccc}
\hline Region & $\mathrm{Cu}$ & $\mathrm{Zn}$ & $\mathrm{Se}$ & $\mathrm{Mn}$ & $\mathrm{Fe}$ & $\mathrm{I}$ \\
\hline Central & $20.01^{\mathrm{c}}$ & $38.84^{\mathrm{b}}$ & $10.69^{\mathrm{b}}$ & $10.69^{\mathrm{b}}$ & $30.66^{\mathrm{b}}$ & 1.18 \\
Eastern & $114.06^{\mathrm{a}}$ & $37.10^{\mathrm{b}}$ & $10.39^{\mathrm{b}}$ & $10.39^{\mathrm{b}}$ & $28.83^{\mathrm{b}}$ & 1.39 \\
Western & $75.58^{\mathrm{b}}$ & $52.45^{\mathrm{c}}$ & $11.99^{\mathrm{b}}$ & $11.98^{\mathrm{b}}$ & $33.69^{\mathrm{b}}$ & 1.65 \\
Southern & $35.03^{\mathrm{c}}$ & $73.69^{\mathrm{a}}$ & $4.05^{\mathrm{c}}$ & $14.05^{\mathrm{c}}$ & $90.26^{\mathrm{a}}$ & 1.02 \\
Northern & $24.03^{\mathrm{c}}$ & $54.36^{\mathrm{c}}$ & $29.89^{\mathrm{a}}$ & $29.89^{\mathrm{a}}$ & $55.74^{\mathrm{c}}$ & 1.25 \\
SEM & 3.20 & 2.70 & 2.31 & 0.98 & 5.32 & 0.06 \\
Significancy & $*$ & $* *$ & $*$ & $* * *$ & $* *$ & $\mathrm{~ns}$ \\
\hline
\end{tabular}

SEM $=$ Standard error of means

Value within column followed with different superscripts are significantly differ

$*=P<0.5 ; * *=P<0.01 * * *=P<0.001$.

Table (3): The some trace minerals concentration in growing camels' whole blood $(\mu \mathrm{g} / \mathrm{ml})$ raised under semi-arid condition of two regions during summer, Saudi Arabia

\begin{tabular}{lccccccc}
\hline Region & $\mathrm{Cu}$ & $\mathrm{Zn}$ & $\mathrm{Se}$ & $\mathrm{Mn}$ & $\mathrm{Fe}$ & $\mathrm{I}$ & Co \\
\hline Central & 4.10 & 4.568 & 1.66 & 4.94 & 13.74 & 0.834 & 1.171 \\
Eastern & 2.31 & 5.153 & 3.34 & 1.36 & 14.81 & 0.1125 & 0.388 \\
SEM & 0.91 & 0.25 & 0.43 & 0.71 & 2.34 & 0.011 & 0.05 \\
Significancy & $*$ & $\mathrm{~ns}$ & $*$ & $*$ & $\mathrm{~ns}$ & $*$ & $*$ \\
\hline
\end{tabular}

SEM = Standard error of means

Value within column followed with different superscripts are significantly differ

$*=P<0.5$. 


\section{Abdelrahman et al.}

Table (4): The some trace minerals concentration in growing camels' rumen fluid $(\mu \mathrm{g} / \mathrm{ml})$ raised under semi-arid condition of two regions during summer, Saudi Arabia

\begin{tabular}{lccccccc}
\hline Region & $\mathrm{Cu}$ & $\mathrm{Zn}$ & $\mathrm{Se}$ & $\mathrm{Mn}$ & $\mathrm{Fe}$ & $\mathrm{I}$ & Co \\
\hline Central & 2.55 & 2.86 & 0.281 & 3.79 & 14.87 & 0.301 & 0.272 \\
Eastern & 1.57 & 2.55 & 0.351 & 3.42 & 4.58 & 1.037 & 0.107 \\
SEM & 0.34 & 0.21 & 0.07 & 0.16 & 0.68 & 0.24 & 0.08 \\
Significancy & $*$ & $\mathrm{~ns}$ & $\mathrm{~ns}$ & $\mathrm{~ns}$ & $*$ & $*$ & $*$ \\
\hline
\end{tabular}

$S E M=$ Standard error of means

Value within column followed with different superscripts are significantly differ

$*=P<0.5$.

Table (5): The some trace minerals concentration in growing camels' rumen tissues $(\mu / \mathrm{g} \mathrm{WW})$ raised under semi-arid condition of two regions during summer, Saudi Arabia

\begin{tabular}{lccccccc}
\hline Region & $\mathrm{Cu}$ & $\mathrm{Zn}$ & $\mathrm{Se}$ & $\mathrm{Mn}$ & $\mathrm{Fe}$ & $\mathrm{I}$ & Co \\
\hline Central & 34.24 & 17.98 & 5.18 & 4.43 & 16.60 & 0.898 & 1.04 \\
Eastern & 115.29 & 22.76 & 5.49 & 4.56 & 14.81 & 0.671 & 0.46 \\
SEM & 14.4 & 0.62 & 0.46 & 0.45 & 1.12 & 0.08 & 0.19 \\
Significance & $*$ & $\mathrm{~ns}$ & $\mathrm{~ns}$ & $\mathrm{~ns}$ & $\mathrm{~ns}$ & $\mathrm{~ns}$ & $*$ \\
\hline
\end{tabular}

$S E M=$ Standard error of means

Value within column followed with different superscripts are significantly differ

$*=P<0.5$. 